\title{
Corporate Liability for Creditors' Losses during the Covid-19 Pandemic
}

\author{
Suwinto Johan ${ }^{1 *}$, Ariawan ${ }^{2}$ \\ ${ }^{1}$ President University, Indonesia \\ ${ }^{2}$ Universitas Tarumanagara, Indonesia \\ *Corresponding author: suwintojohan@gmail.com
}

\begin{tabular}{l} 
ARTICLE INFO \\
\hline Keywords: \\
bankruptcy; corporate \\
liability; covid-19 \\
pandemic; limited liability \\
company \\
How to cite: \\
Johan, S. \& Ariawan. \\
(2021). Corporate \\
Liability for Creditors' \\
Losses during the \\
Covid-19 Pandemic. \\
Jurnal Media Hukum, \\
28(1), 15-28. \\
Article History: \\
Received: 09-12-2020 \\
Reviewed: 01-03-2021 \\
Revised: 19-06-2021 \\
Accepted: 30-06-2021
\end{tabular}

\begin{abstract}
Many companies experienced bankruptcy lawsuits during the Covid19 pandemic in 2020. This was so when the companies' asset cannot afford their obligations upon their creditors, especially banks and other financial institutions. The creditors demanded compensation to avoid losses due to the companies' failure in repaying their loans. The question is who should be held liable if the companies are of limited liability companies. This paper aims to examine the liability of corporation for creditors' losses. This normative legal research relies on secondary data in the form of legal materials, especially primary and secondary legal materials. The result shows that demanding compensation through bankruptcy lawsuit is not an easy task for the creditors. In fact, a separate lawsuit is required rather than incorporating it in a bankruptcy lawsuit. Even, it is not only a matter of civil case but also criminal case. Therefore, the companies may be subjected to both civil and criminal liability.
\end{abstract}

DOI: https://doi.org/ 10.18196/jmh.v28i1.10566

Copyright (C) 2021 JURNAL MEDIA HUKUM. All rights reserved.

\section{Introduction}

The Covid-19 pandemic has caused a global economic recession. It has been reported that as many as 42 countries have experienced negative economic growth in the second quarter of 2020 due to this recession. ${ }^{1}$ Indonesia's economic growth has also been affected. ${ }^{2}$ Many Indonesian companies have experienced a decline in turnover,

\footnotetext{
${ }^{1}$ Arbar, T. F. (2020). 42 Negara Ekonominya dihancurkan Covid-19 Resesi Itu Nyata, diakses dari https://www.cnbcindonesia.com/news/20200831070523-4-183144/42-negaraekonominya-dihancurkan-covid-19-resesi-itu-nyata dated 14 October 2020.

${ }^{2}$ Kusuma, H. (2020). Ramalan Terbaru IMF Ekoomi RI $-1.5 \%$ di 2020 downloaded from https:// finance.detik.com/berita-ekonomi-bisnis/d-5212852/ramalan-terbaru-imf-ekonomi-ri-

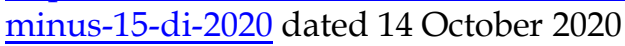


resulting in liquidity problems. Many corporations have engaged in termination of employment for survival ${ }^{3}$

During the pandemic, there were a number of companies that made retrenchments 17.8 percent of firms. Additionally, 25.6 percent of firms lay off workers, and 10 percent of firms do both. ${ }^{4}$ The World Labor Organization (ILO) stated that two out of three companies surveyed in Indonesia had either temporarily or permanently stopped their business operations. ${ }^{5}$ As many as $40 \%$ of retail convenience stores have closed as consumers' purchasing power has decreased during the pandemic. ${ }^{6}$

The number of companies experiencing the process of postponing Suspension of Debt Payment Obligations (PKPU) has also increased during the pandemic. ${ }^{7}$ The ability to pay corporate obligations decreases during large-scale social restrictions. This is in line with the decline in sales due to weakening public demand. Since the corporations had difficulty in obtaining sales, they were unable to cover operational costs and suffered losses. ${ }^{8}$

Being exposed to bankruptcy lawsuit or Suspension of Debt Payment Obligations, the corporations may go bankrupt and their assets will be confiscated and auctioned off by the Curator. ${ }^{9}$ The problems arises when the value of asset cannot afford their obligations to their creditors and this will cause the creditors suffering an unexpected loss. Should the corporation entities, especially the board of directors (BOD), be held accountable if the creditor experiences a loss?

The responsibility of corporation organs, especially directors, has always become a matter of debate. Many studies have been focused on the accountability of the BOD and other corporate organs. This research is unique in that the focus of this study is on the accountability of directors to creditors associated with bankruptcy and postponement of debt payment obligations (PKPU). Research focuses on accountability to creditors, including those related to bankruptcy and PKPU. This research will stipulate added values to the demand for accountability of directors and boards of commissioners (BOC) of companies experiencing bankruptcy.

\footnotetext{
${ }^{3}$ M aulidya, I. (2020) 73 Perusahaan Lakukan PHK Hampir 15.000 Pekerja Jadi Pengangguran downloaded from https://economy.okezone.com/read/2020/07/10/320/2244240/73perusahaan-lakukan-phk-hampir-15-000-pekerja-jadi-pengangguran dated 14 October 2020

${ }^{4}$ Sulaeman (2021) Menaker: 17,8 Persen Perusahaan PHK Karyawan Selama Pandemi Covid-19 downloaded from https://www.merdeka.com/uang/menaker-178-perusahaan-phk-karyawan-selamapandemi-covid-19.html\# dated 23 April 2021.

${ }^{5}$ Hadyan, R. (2020) Survei ILO: Dua dari Tiga Perusahaan di Indonesia Berhenti Beroperasi downloaded from https://ekonomi.bisnis.com/read/20200518/12/1242174/survei-ilo-dua-dari-tiga-perusahaan-diindonesia-berhenti-beroperasi date 23 April 2021.

${ }^{6}$ Liputan6.com (202)) 40 Persen Swalayan di Indonesia Timur Tutup Imbas Pandemi Covid-19 downloaded from https://www.liputan6.com/bisnis/read/4402525/40-persen-swalayan-di-indonesiatimur-tutup-imbas-pandemi-covid-19\# dated 23 April 2021.

${ }^{7}$ Susanto, V. Y. (2020) Tren Perkara PKPU Meningkat di Tengah Pandemi Covid-19 diakses dari https://nasional.kontan.co.id/news/tren-perkara-pkpu-meningkat-di-tengah-pandemi-covid-19 dated 14 October 2020.

${ }^{8}$ Kencana, M. R. B. (2020). Chatib Basri: Akibat PSBB Perusahaan Menjadi Zombie Akibat Sulit Tutup Biaya Usaha downloaded from https://www.liputan6.com/bisnis/read/4381091/chatib-basri-akibat-psbbperusahaan-jadi-zombie-akibat-sulit-tutup-biaya-usaha dated 14 October 2020.

${ }^{9}$ Parwito. (2020). Pailit Aset PT. Nyonya Meneer Harus Dilelang Untuk Lunasi Utang downloaded from https://www.merdeka.com/peristiwa/pailit-aset-pt-nyonya-meneer-harus-dilelang-untuk-lunasi-utang.html dated 14 October 2020.
} 
Corporate liabilities have become issues resulting the rise in commercial crimes. ${ }^{10}$ Many companies deliberately file a loss in order not to pay off debts. Many financial institutions suffer losses as a result of the actions.

This research has novelty in discussing the responsibility of directors for corporation losses during the pandemic that occurred in 2020. This research delivers a general view on the form of directors' responsibility for creditors, especially during the Covid-19 Pandemic. Creditors, especially banks, will have knowledge on the bankruptcy liability of the corporation or PKPU. Creditors will be able to remember the corporation in the credit agreement. This research is unique in providing added value to creditors, especially financial institutions. This research focuses on responsibility of debtors in the form of limited companies, not a retail debtor.

Based on the background above, this study aims to examine:

1. What is the corporation's responsibility, especially the board of directors, for creditors' losses under the Limited Liability Corporation Law during the Covid19 Pandemic?

2. How can the corporation's entities, especially the BOD, be held accountable for its losses when the corporate facing bankruptcy due to the pandemic of Covid19 ?

\section{Method}

This normative legal research carried out by examining secondary (library) data in the form of legal materials, which can be further divided into primary, secondary and tertiary legal materials. The researchers have studied legal principles, legal norms, and legal theories relevant to this research. In addition, as this normative legal research employs statutory approach, all relevant laws and regulations have also been reviewed.

\section{Analysis and Results}

Business actors prefer to use limited liability company in operating their business. Since there is separation between personal assets and corporate assets, there will also be separation between personal and corporate liabilities. This separation of a liability may secure the personal assets from external parties' claims. A limited liability corporation, referred to as a corporation or firm, is a legal entity which is a form oof capital cooperation, founded by a contract, steering or operating business activities with an authorized investment which is entirely distributed into stocks and fulfills the requirements stipulated in the Act on Companies along with the regulation on the implementations. ${ }^{11}$

\footnotetext{
${ }^{10}$ Ali, M. (2019). From Separate Legal Entity to Economic Unity: The Criminal Liability of Parent Corporation. Jurnal Media Hukum, 26(2), 158-167. https://doi.org/10.18196/jmh.20190131

11 Lubis, M. F. R. (2018). Pertanggungjawaban Direksi di Suatu Perseroan Terbatas Ketika Terjadi Kepailitan pada Umumnya dan Menurut Doktrin Hukum dan Menurut Doktrin Hukum Perusahaan \& Undang Undang No. 40 Tahun 2007. Jurnal Hukum Kaidah, 17(2)
} 
The following are examples of several cases where directors were charged with crimes against various backgrounds of incidents.

1. The BOD is a suspect in a criminal case, where the corporation is in the PKPU process. Three directors of PT. Sunprima Nusantara Financing were detained by the police. The three directors were charged for committing the crime of money laundering (TPPU). ${ }^{12}$

2. A corporation's managing director and finance director were reported to the National Police Headquarters on suspicion of criminal acts in a corporation bankruptcy case. The two directors were accused of using bankruptcy assets without the curator's permission, causing losses to creditors. ${ }^{13}$

3. Three Jiwasraya directors were sentenced to life imprisonment due to criminal acts of corruption. The verdict is based on the direct indictment of Article 2 Paragraph (1) in conjunction with Article 18 of Number 31 of 1999 Act as amended by Act Number 20 of 2001 on Eradication of Corruption in concurrence with Article 55 Paragraph (1) 1st of the Criminal Act. ${ }^{14}$

4. Former President Director of PT Bank DKI, Winny Erwindia, was sentenced to 4 years in prison, a fine of IDR 250 million, three months in jail for corruption. The Judges panel stated that Winny was proven guilty of corruption related to the loan agreement to finance the purchase of ATR 42-500 aircraft that was submitted by PT Energy Spectrum (PT ES), as in the direct indictment of Article 2 paragraph 1 of Act Number 31 Year 1999 on Eradication of Corruption Crime as amended by Act Number 20 of 2001 in concurrence with Article 55 Paragraph 1-1 of the Criminal Act. ${ }^{15}$

The BOD responsibilities in running a limited liability corporation as stipulated in the Corporation Act Year 2007 are connected to their responsibilities and authorities in carrying out the corporation's management for the advantage of the corporation and following the corporation's goals and purposes. In managing the corporation, the BOD has the power to manage the corporation under rules that are considered suitable, within restrictions stipulated in the Corporation Act Year 2007 and the deed of establishment. ${ }^{16}$ Based on the fiduciary duty and Business Judgment Rule for directors and commissioners, the introductory provisions governing the management

\footnotetext{
12 Septiadi, A. (2018). Tiga Direktur Ditahan Polisi, PKPU SNP Finance terhambat downloaded from https://nasional.kontan.co.id/news/tiga-direktur-ditahan-polisi-pkpu-snp-finance-terhambat dated 14 October 2020

13 Edj (2009). Dituduh Gunakan Harta Pailit Direksi TPI Dilaporkan Kurator downloaded from https://money.kompas.com/read/2009/11/20/18394268/dituduh.gunakan.harta.pailit.direksi.tpi.dilaporkan .kurator dated 14 October 2020.

${ }^{14}$ Bramasta, D. B. (2020) Profil Tiga Mantan Direksi PT. Asuransi Jiwasraya Yang Divonis Seumur Hidup downloaded from https://www.kompas.com/tren/read/2020/10/13/103618365/profil-tiga-mantandireksi-pt-asuransi-jiwasraya-yang-divonis-seumur-hidup?page=all dated 14 October 2020.

15 Detik.com. (2020) Eks Dirut Bank DKI Winny Erwindia Divonis 4 Tahun Penjara diaskses pada https://news.detik.com/berita/d-2834887/eks-dirut-bank-dki-winny-erwindia-divonis-4-tahun-penjara dated 14 October 2020.

16 Raffles. (2020). Tanggung Jawab dan Perlindungan Hukum Direksi Dalam Pengurusan Perseroan Terbatas. Undang: Jurnal Hukum, 3(1), 107-137. DOI: 10.22437/ujh.3.1.107-137
} 
responsibilities, obligations, and the responsibilities of the managements of a limited liability corporation in the Corporation Act must be considered 17

Each member of BOD must have good trust and be full of accountability in functioning their responsibilities for the corporation's benefit. Suppose in carrying out his responsibilities. There are indications that a director misuses power given to him for individual gain and origins financial losses that lead to its bankruptcy. In that case, the director can be held personally accountable or his assets can be used to guarantee settlement of the corporation's obligations that are in the process of liquidation. 18

Besides, there are instances where the directors committed an abuse of authority. Arjuna Finance guarantees Certificate of Ownership of Motor Vehicles to more than one creditor. ${ }^{19}$ Guarantee of collateral to more than 1 creditor or called multi-pledge collateral side streaming. ${ }^{20}$ Side streaming is the use of loan funds from banks outside those specified in the credit agreement. Side streaming is an act of misuse of credit funds and is the BOD's responsibility, if the debtor is a corporation. ${ }^{21}$ Banks have a huge risk in lending, so bank need an additional collateral such as guarantees. ${ }^{22}$

The corporation is not accountable for the BOD's actions that attempt beyond the power given to it by the deed of establishment. A director can be seized individually accountable if the corporation goes bankrupt due to its errors or negligence in managing the organization and representatives of the corporation, which resulted in the corporation going bankrupt. ${ }^{23}$

Suppose the BOD makes business decisions that cause losses to the corporation due to ultra vires or exceeding the power as stipulated in the articles of association or related rules and regulations. In that case, a director cannot be sheltered by the business judgment rule doctrine. If the director takes ultra vires actions, then the director may be exposed to Article 97 Paragraph (3) of the Limited Liability Corporatin Act. This paper statuses that each member of the BOD is entirely accountable and his private assets if the director commits an error or negligence, resulting in the corporation experiencing a loss. ${ }^{24}$

\footnotetext{
${ }^{17}$ Hasnati, S. D. (2019). Mengenal Fiduciary Duty and Business Judgement Rule Direksi dan Komisaris. Eksiklopedia Social Review, 1(2): 111-116

${ }^{18}$ Yanuarsi, S. (2020). Kepailitan Perseroan Terbatas Sudut Pandang Tanggung Jawab Direksi. Solusi., 18(2): 283-297

19 Septiadi, A. (2020) Sengkarut BPKB Dalam Pailit Arjuna Finance downloaded from https://nasional.kontan.co.id/news/sengkarut-bpkb-dalam-pailit-arjuna-finance dated 14 October 2020.

${ }^{20}$ Septiadi, A. (2020). Pembelaan Manajemen Arjuna Finance Atas Kasus Utang Yang Membelitnya downloaded from https://nasional.kontan.co.id/news/pembelaan-manajemen-arjuna-finance-atas-kasusutang-yang-membelitnya dated 14 October 2020.

${ }^{21}$ Yani, M. A. \& Mustofa, M. (2019) Prevention Model of Disguised Crime in Indonesian Banking Facing the Deviation Actions of The Credit Use/Side Streaming by Debtors; Theoretical Review on Risk Management of Default Side Streaming. Jurnal Cita Hukum, 7(2): 199-212, DOI: $10.15408 /$ jch.v7i2.12115

${ }^{22}$ Badriyah, S. M. (2015). Kreditor Dalam Penggunaan Base Transceifer Station ( BTS ) Sebagai Objek Jaminan Fidusia Dalam Perjanjian Kredit. Jurnal Media Hukum, 22(2), 207-217. https://doi.org/10.18196/jmh.2015.0056/

${ }^{23}$ Pradhana, A. P. (2015) Tanggung Jawab Direksi Perseroan Terhadap Preseroan Yang Dinyatakan Pailit. Yustisia Merdeka, 1(2): 15-28

${ }^{24}$ Akbar, M. G. G. (2016). Business Judgemen Rule Sebagai Perlindungan Hukum Bagi Direksi Perrseroan Dalam Melakukan Transaksi Bisnis. Jurnal Justisi Ilmu Hukum, 1(1): 1-15
} 
The BOD of the corporation is one of the entities of the corporation which has the responsibility to do daily management activities of the corporation, for the best goods of the corporation in accord with the aims and purposes of the corporation and to represent the corporation both inside and outside the law court in accordance with the provisions of limited liability corporation's charter.25

Based on Article 97 Paragraph 1 of the Limited Liability Corporation Act (UU PT), the BOD is accountable for managing the corporation. In Paragraph 3, each member of the BOD is fully accountable for the corporation's loss if the director concerned is blameworthy or negligent in carrying out his responsibilities.

If the BOD comprises of 2 (two) members or more, this is joint responsibility for each member of the BOD. Based on Article 97 Paragraph 5 of the Limited Liability Corporation Act Year 2007, if the BOD can prove that the corporation's losses are not due to his or her mistakes or negligence; has running the management in good attention and prudently for the interest of and in accordance with the aims and purposes of the corporation; does not take a conflict of individu interest, either directly or indirectly, over management decisions that result in losses; and have taken appropriate steps to avert the loss from happening or unending.

Apart from the BOD, each member of the BOC is also individually accountable for the corporation's losses if the commissioner concerned is responsible or negligent in doing out his/her responsibilities based on Article 114 Paragraph 3 of the Limited Liability Corporation (LLC) Act.

Creditors experiencing losses due to corporation bankruptcy is a common thing. The corporation losses are allegedly caused by the directors' negligence and negligence of supervision by the commissioners. The process of holding the directors accountable as stated in article 97, paragraph 1 LLC Act Year 2007 and the commissioners' accountability based on article 114 paragraph 3 is not clearly explained in the Limited Liability Corporation. Meanwhile, the corporation has gone bankrupt.

3.1. Responsibility of the Board of Directors for Losses of Creditors of Limited Liability Companies during the Covid-19 Pandemic

Internal corporation operations or external factors can cause corporation losses. The failure of the corporation's internal operations can be caused by management failure to foresee transformations in the macro-environment, such as modifications in consumer behavior and technology changes. Internal factors can also take the form of fire, failure, or technical, operational disruptions, such as the impact of strikes and defects in production rather than production systems. External factors can also cause a corporation to experience difficulties in running its business. External factors such as government policies in the monetary and fiscal sectors and the occurrence of natural disasters such as the Covid-19 Pandemic. External factors of the corporation, such as changes in political and macroeconomic conditions and force majeure. Economic factors, such as the 1998 Asian monetary crisis, the 2008 global financial crisis, and other economic crises. Force majeure crises, such as earthquakes, tsunamis, volcanic eruptions, or floods.

\footnotetext{
${ }^{25}$ Isfardiyana, S. P. (2017) Business Judgement Rule Oleh Direksi Perseroan. Jurnal Panorama Hukum, 2(1), $1-20$
} 
Internal operational factors of the corporation are factors that are the responsibilities of the BOD. BOD must be able to resolve all obstacles and restore its original operational condition. Directors must also be able to predict changing conditions due to changes in the environment and consumer behavior.

Corporation losses can also be caused by the directors' decisions or actions for personal gains, such as self-enrichment or dealings that have a conflict of individual interest. Transactions involving the related directors are possible if they have obtained approval under the deed of establishment of the corporation and the relevant rules and regulations under Article 99 Paragraph 1 of the Limited Liability Corporation Act, members of the BOD are not given the authority to embody the corporation if: there is a case in law court between the corporation and the member of the BOD concerned; or the member of the BOD concerned has a conflict of concern with the corporation.

All transactions that occur in the corporation should be contained in the financial statements. Article 69 Paragraph 3 of the Limited Liability Corporation Law, in the event that the financial reports provided are found to be false and/or misleading, members of the BOD and members of the BOC are jointly and severally accountable for the injured party. In comparison, Article 69 Paragraph 4, members of the BOD and and members of the BOC are exempt from responsibility if it is proven that the condition is not due to their fault.

Creditors are the parties who will hold the corporation accountable if the debt to creditors is not able to be repaid by the corporation. Creditors consist of creditors who have guarantees or are called separatists or preferred creditors, and concurrent creditors are creditors who have no guarantees. Separatist creditors are generally banking creditors or financing creditors. The separatist creditor is the creditor who holds collateral rights over the material, and the separatist creditor can sell the collateral himself and take it himself from the sale proceeds. ${ }^{26}$

Meanwhile, concurrent creditors are transaction creditors or trade debt creditors. A concurrent creditor is an unsecured creditor which results in the creditor unable to seize collateral and auction off the collateral object. 27

Figure 1. Corporation's Bankruptcy and Suspension of Debt Payment Obligations Process

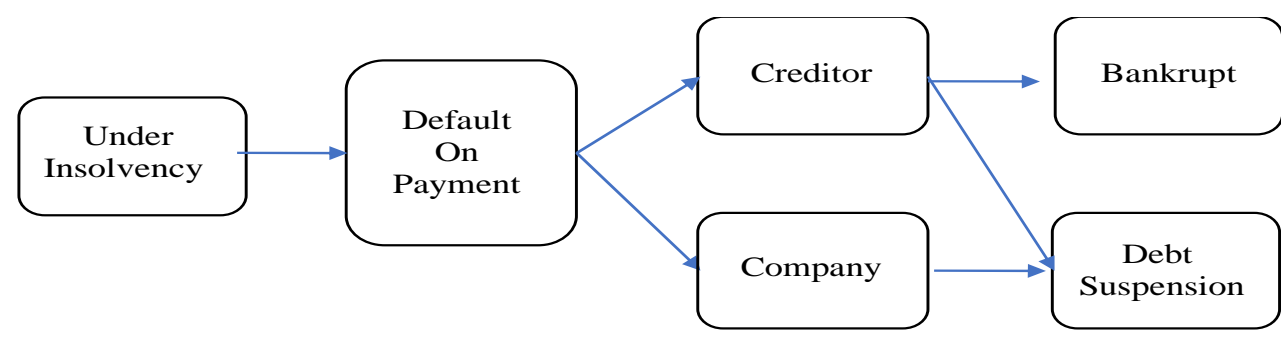

Source: Research Result

\footnotetext{
${ }^{26}$ Prastika, K. S. D., Marwanto., Sukranatha, A. A. K., (2017). Kedudukan Kreditur Dalam Perjanjian Kredit Dengan Jaminan Hak Milik Atas Tanah Berdasarkan Undang Undang No. 4 Tahun 1997 Tentang Hak Tanggungan Beserta Benda-Benda Yang Berkaitan Dengan Tanah. Kertha Semaya, 5(1).

27 Makawimbang, R. D. (2016). Upaya Kreditur (Bank) Untuk Mendapatkan Jaminan Pembayaran Perjanjian Kredit Akibat Objek Jaminan Berpindah Tangan Karena Putusan Pengadilan. Jurnal Hukum Mahasiswa
} 
The corporation's ability to settle its obligations reflects the corporation's condition. If the corporation has difficulty paying its obligations to creditors, the corporation will experience financial distress. With financial distress, the corporation has difficulty repaying its debt. This is illustrated in Figure 1. This research focuses on companies that experience losses and are unable to pay their obligations. Not being able to pay off the loan can lead to bankruptcy and reorganization of debt.

The creditor will demand payment of obligations to him. Creditors can file for Liquidation or Suspension of Debt Payment Obligations (PKPU) if not paid. Thus, the condition of the corporation will be clearly visible. If the corporation is unable to pay, the BOD and/or BOD can be held accountable.

The principles of Business Judgement Rules are regulated in Article 97 Paragraph (5) of Act No. 40 of 2007 on Limited Liability Corporation Act. Based on this principle, the directors of who make business decisions that result in losses for state-owned companies cannot be held personally accountable provided that the business decisions are made based on good faith and prudence. ${ }^{28}$

In addition, companies can submit PKPU to the commercial court or reorganization debt proposals to all creditors due to external factors such as pandemic Covid-19. However, if the corporation experiences deep difficulties, the corporation will file for bankruptcy. The responsibility of the director cannot be avoided, but if the bankruptcy is due to external conditions or factors, the director cannot be held personally accountable.

\subsection{The Board of Directors' Accountability Process for Losses of Limited Liability Companies facing bankruptcy due to the pandemic of Covid-19}

The corporation is a limited liability corporation, went bankrupt after going through a commercial court process. The curator manages the confiscation of the corporation's assets and the proceeds from the auction of the assets are used to pay their obligations. If the assets' value is smaller than the liabilities, the creditors will not get a loss. Payment will be less than creditors claim.

Assets consist of liabilities plus the corporation's capital. Therefore, it is fitting that if the corporation is running normally, the assets are greater than the liabilities. Assets below its liabilities are generally caused by negative capital. Negative capital is caused by losses.

Conversely, if the corporation has assets above liabilities, then the corporation has the ability to pay the liabilities claimed by creditors. This rarely happens, because if the corporation is in good condition and running, bankruptcy rarely occurs. In most cases, the corporation experienced a loss, so that the capital was negative. Due to negative capital, the corporation has difficulty paying obligations that are due. With an obligation that is due, the corporation is in default. With this default, the creditor filed for Liquidation or Suspension of Debt Payment Obligations. (PKPU).

Due to the lack of payment of obligations to creditors, the creditors will examine the causes of the corporation's losses. If this loss is not caused by the negligence of the directors or commissioners of the corporation, the directors and commissioners do not

\footnotetext{
${ }^{28}$ Pramagitha, P. A. \& Sukranatha, A.A. K. (2019) Prinsip Business Judgement Rule Sebagai Upaya Perlindungan Terhadap Keputusan Bisnis Direksi BUMN. Kertha Semaya, 7(12)
} 
need to be accountable under Article 69 paragraph 4 of the Limited Liability Corporation Act.

If negligence is found, then the creditor can ask the BOD and/or BOD for responsibility. If it is a civil case, the creditor must review whether the transaction that caused the loss was reported in the annual report and its financial report. If it is contained in financial reports and/or annual reports, creditors need to know whether the corporation's General Meeting has approved the financial statements and / or annual reports of Shareholders. If it is approved, it should be reviewed whether it has been given acquit et discharge or not.

If it has not been reported in the annual corporation report and/or audited financial report, it can be concluded that there is no report yet at the Annual Shareholders Meeting. In the absence of a Annual Shareholders Meeting, acquit et discharge is also not given to the BOD. Thus, this substance becomes the director's negligence regarding this transaction. Directors can be held accountable, because this transaction is not reflected in the annual corporation report or annual financial audited report. The explanation of this is illustrated in Figure 2.

Figure 2. Process of Suspension of Debt Payment Obligations (PKPU) to Director's Responsibilities

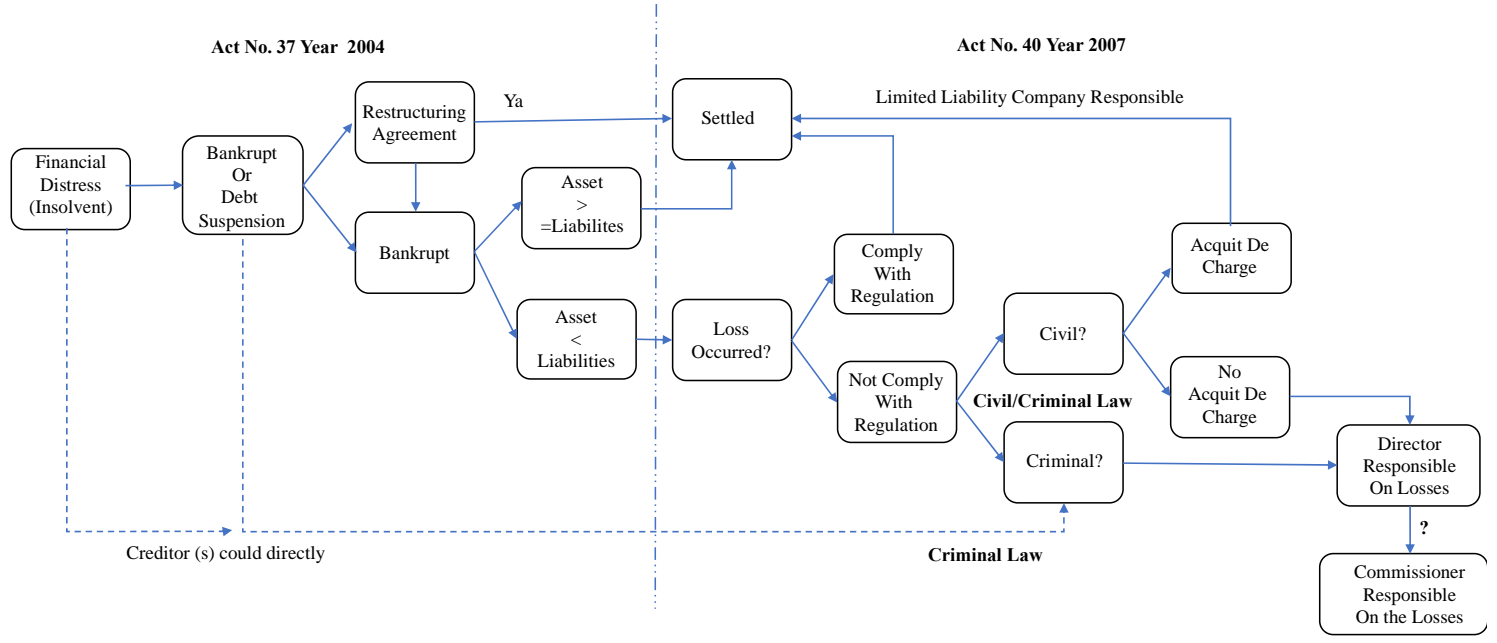

Source: Research Result

If there are indications of a crime, the creditor can hold the BOD accountable. Criminal acts include negligence by causing losses to the corporation. ${ }^{29}$ An example of negligence is using the corporation funds not according to their allocation. Other criminal acts, such as using corporation funds for personal gain and using corporation

${ }^{29}$ Yani, M. A. \& Mustofa, M. (2019) Prevention Model of Disguised Crime in Indonesian Banking Facing the Deviation Actions of The Credit Use/Side Streaming by Debtors; Theoretical Review on Risk Management of Default Side Streaming. Jurnal Cita Hukum, 7(2). 199-212, DOI: 10.15408/jch.v7i2.12115 
facilities for personal gain. ${ }^{30}$ The use of corporation funds for personal gain is called side streaming

If this happens, the creditor can report a criminal act committed by the BOD or BOC. ${ }^{31}$ Thus, the directors or commissioners must be accountable for their actions that are suspected of causing harm to the corporation. Based on Article 97 Paragraph 3, Article 104 Paragraph 1 and Article 115 paragraph 1 of the Limited Liabilities Corporation Act, the BOD must bear the loss with their personal assets. ${ }^{32}$

In code, a member of BOD is not individually accountable for actions devoted for and on behalf of the corporation based on its power. This is because the decisions of the BOD are seen as decisions of the corporation which are independent legal subjects so that the corporation is accountable for the decisions of the corporation itself which in this case is symbolized by the BOD. ${ }^{33}$

The BOD in a limited liability corporation can be related to the existence of a corporation. The BOD is functioning its responsibilities to manage a limited liability corporation has the risk of committing acts against the rules and regulations, both criminal and civil. 34

There are regulations or articles in the law that oblige the corporation to place collateral for the personal assets of the BOD who are proven to have committed illegal acts so that the results of the decision can be carried out according to the reasons for the claim of the principle of piercing the corporate veil in order to achieve the main goal of achieving justice particularly third parties and to create public order (open bare conduct). ${ }^{35}$

The personal responsibility of members of the BOD will be connected to the presence or absence of errors or omissions committed by members of the BOD in managing and representing the corporation. The position of a corporation that is declared bankrupt does not automatically stop and dissolve, but it still exists as a legal entity of the corporation because there are still certain processes and stages from the time it is declared bankrupt to the completion of settlement of bankruptcy assets from the corporation 36

\footnotetext{
30 Al Hikam, H. A. (2019) Kronologi Kisruh Sushi Tei Vs Eks Dirut diunduh dari https://finance.detik.com/berita-ekonomi-bisnis/d-4701012/kronologi-kisruh-sushi-tei-vs-eks-dirut dated 18 October 2020.

${ }^{31}$ Septiadi, A. (2018). Tiga Direktur Ditahan Polisi, PKPU SNP Finance terhambat downloaded from https://nasional.kontan.co.id/news/tiga-direktur-ditahan-polisi-pkpu-snp-finance-terhambat dated 14 October 2020

${ }^{32}$ Hasanah, S. (2019) Tanggung Jawab Direksi dan Komisaris Jika Perusahaan Pailit diunduh dari https://www.hukumonline.com/klinik/detail/cl4898/tanggung-jawab-direksi-dan-dewan-komisaris-jikaperusahaan-pailit/ dated 18 October 2020.

33 Setianto, V. Y. (2017) Pertanggungjawaban Pribadi Direksi Pada Perseroan Terbatas Yang Pailit. Mimbar Yustitia, 1(2), 202-221

${ }^{34}$ Setyarini, D. M., Mahendrawati, Ni Luh M., Arini, D Gde D., (2020) Pertanggungjawaban Direksi Perseroan Terbatas Yang Melakukan Perbuatan Melawan Hukum. Jurnal Analogi Hukum, 1(2): 12-16

${ }^{35}$ Harahap, P. S., \& Tumanggor., (2015). Penerapan Asas Piercing The Corporate Veil: Perspektif Tanggung Jawab Direksi Perseroan Terbatas. Jurnal Nuansa Kenotahiatan,1(1): 45-52

36 Widjajati, E. (2017) Tanggung Jawab Direksi Perseroan Terbatas Yang Dinyatakan Pailit. Selisih, 3(5): 17-32.
} 
In code, the BOD is not individually accountable for actions devoted for and on behalf of the corporation based on its power. This is because the actions of the BOD are seen as decisions of the corporation which are independently subject to law so that the corporation is accountable for the decisions of the corporation itself which in this case is represented by the BOD. The scope of actions held personally accountable by the corporation director is carelessness because the director does not fulfill the substances of the contract and mistakes because the directors have committed illegal undertakings. ${ }^{37}$

\section{Conclusion}

Requests for corporate liability begin with the corporation's ability to reimburse its commitments. If the corporation is unable to pay its commitments that are due, then the corporation will experience default. Creditors can apply for Liquidation or Suspension of Debt Payment Obligations. After the Liquidation or Suspension of Debt Payment Obligations process, if the corporation goes bankrupt, it will review the BOD and BOC's responsibilities. Creditors who experience losses can hold corporation organs, such as directors and BOC, accountable if misconduct is found. However, if the corporation's losses are a result of the Covid-19 pandemic, then directors and other organs of the corporation cannot be held personally accountable. A director is held accountable if he has taken advantage or enjoyment personally, including during the Covid-19 pandemic. A pandemic event is not an event generated by the policy of the BOD. If there is any negligence, the director and commissioner can be held accountable. Requests for liability for losses to corporation's entities' negligence cannot easily be proven. Requests for liability for losses must be pursued in a separate case from the corporation bankruptcy. Requests for accountability must be viewed from civil and criminal codes' perspectives. If the corporation's entities have been given an acquit et discharge, then the civil case will be the responsibility of the corporation. If the dealings that result in losses have not been stated, the new corporation's entities will be held accountable, both from a civil and criminal codes' perspective. Suppose there is a usage of corporation funds or conveniences for the BOD or BOC's benefit. In that case, the responsibility can the corporation's responsibility sanctions conducted by directors or commissioners need to be reviewed in the annual report or financial report submitted at each Shareholders Meeting. Therefore, BOD and BOC can be held accountable if the corporation is unable to reimbursement its debts to creditors and it is proven that there has been abuse of authority. Apart from abuse of authority, directors and commissioners can be held accountable if there is a conflict of interest in making decisions. If the director has implemented a business judgment rule in the interests of the corporation during the pandemic of Covid-19. Then the director cannot be held accountable.

\footnotetext{
${ }^{37}$ Gea, A. F., Hirsanuddin., Djumardin. (2020). Tanggung Jawab Direksi Atas Terjadinya Pailit Perseroan Terbatas. Journal of Education on Social Science, 4(1), 83-98. DOI:https://doi.org/10.24036/jess/vol4iss1
} 


\section{References}

\section{Journal}

Akbar, Muhammad, G. G. (2016). Business Judgemen Rule Sebagai Perlindungan Hukum Bagi Direksi Perrseroan Dalam Melakukan Transaksi Bisnis. Jurnal Justisi Ilmu Hukum, 1(1): 1-15

Ali, M (2019). From Separate Legal Entity to Economic Unity: The Criminal Liability of Parent Corporation. Jurnal Media Hukum, 26(2), 158-167. https:/ / doi.org/10.18196/jmh.20190131

Badriyah, S. M. (2015). Kreditor Dalam Penggunaan Base Transceifer Station ( BTS ) Sebagai Objek Jaminan Fidusia Dalam Perjanjian Kredit. Jurnal Media Hukum, 22(2), 207-217. https:// doi.org/10.18196/jmh.2015.0056/

Gea, A. F., Hirsanuddin., Djumardin. (2020). Tanggung Jawab Direksi Atas Terjadinya Pailit Perseroan Terbatas. Journal of Education on Social Science. 4(1): 83-98. DOI:https://doi.org/10.24036/jess/vol4-iss1

Harahap, P. S., \& Tumanggor. (2015). Penerapan Asas Piercing The Corporate Veil: Perspektif Tanggung Jawab Direksi Perseroan Terbatas. Jurnal Nuansa Kenotahiatan, 1(1): 45-52

Hasnati, S. D. (2019). Mengenal Fiduciary Duty and Business Judgement Rule Direksi dan Komisaris. Eksiklopedia Social Review,1(2): 111-116

Isfardiyana, S. H. (2017) Business Judgement Rule Oleh Direksi Perseroan. Jurnal Panorama Hukum, 2(1): 1-20

Lubis, M. F. R. (2018). Pertanggungjawaban Direksi Di Suatu Perseroan Terbatas Ketika Terjadi Kepailitan Pada Umumnya Dan Menurut Doktrin Hukum Dan Menurut Doktrin Hukum Perusahaan \& Undang Undang No. 40 Tahun 2007. Jurnal Hukum Kaidah, 17(2)

Makawimbang, R. D. (2016). Upaya Kreditur (Bank) Untuk Mendapatkan Jaminan Pembayaran Perjanjian Kredit Akibat Objek Jaminan Berpindah Tangan Karena Putusan Pengadilan. Jurnal Hukum Mahasiswa

Pradhana, A. P. (2015) Tanggung Jawab Direksi Perseroan Terhadap Preseroan Yang Dinyatakan Pailit. Yustisia Merdeka, 1(2): 15-28

Pramagitha, P. A., dan Sukranatha, A.A. Ketut. (2019) Prinsip Business Judgement Rule Sebagai Upaya Perlindungan Terhadap Keputusan Bisnis Direksi BUMN. Kertha Semaya, $7(12)$

Prastika, K. S. D., Marwanto., Sukranatha, A. A. K. (2017). Kedudukan Kreditur Dalam Perjanjian Kredit Dengan Jaminan Hak Milik Atas Tanah Berdasarkan Undang Undang No. 4 Tahun 1997 Tentang Hak Tanggungan Beserta Benda-Benda Yang Berkaitan Dengan Tanah. Kertha Semaya, 5(1)

Raffles., (2020). Tanggung Jawab dan Perlindungan Hukum Direksi Dalam Pengurusan Perseroan Terbatas. Undang: Jurnal Hukum, 3(1): 107-137. DOI: 10.22437/ujh.3.1.107-137

Setianto, V. Y. (2017) Pertanggungjawaban Pribadi Direksi Pada Perseroan Terbatas Yang Pailit. Mimbar Yustitia, 1(2): 202-221 
Setyarini, D. M., Mahendrawati, Ni Luh M., Arini, D Gde D., (2020) Pertanggungjawaban Direksi Perseroan Terbatas Yang Melakukan Perbuatan Melawan Hukum. Jurnal Analogi Hukum, 1(2): 12-16

Widjajati, E. (2017) Tanggung Jawab Direksi Perseroan Terbatas Yang Dinyatakan Pailit. Selisih, 3(5): 17-32.

Yani, M. A. \& Mustofa, M. (2019) Prevention Model of Disguised Crime in Indonesian Banking Facing the Deviation Actions of The Credit Use/Side Streaming by Debtors; Theoretical Review on Risk Management of Default Side Streaming. Jurnal Cita Hukum, 7(2): 199-212, DOI: 10.15408/jch.v7i2.12115

Yanuarsi, S. (2020). Kepailitan Perseroan Terbatas Sudut Pandang Tanggung Jawab Direksi. Solusi,18(2): 283-297

\section{Law and Regulation}

Law Number 40 of 2007 on Limited Liability Corporation

Law Number 37 of 2004 on Bankruptcy and Suspension of Debt Payment Obligations

\section{Other Sources}

Arbar, T. F. (2020). 42 Negara Ekonominya dihancurkan Covid-19 Resesi Itu Nyata, diakses dari https://www.cnbcindonesia.com/news/20200831070523-4183144/42-negara-ekonominya-dihancurkan-covid-19-resesi-itu-nyata dated 14 October 2020.

Bramasta, D. B. (2020) Profil Tiga Mantan Direksi PT. Asuransi Jiwasraya Yang Divonis Seumur Hidup downloaded from https://www.kompas.com/tren/read/2020/10/13/103618365/profil-tigamantan-direksi-pt-asuransi-jiwasraya-yang-divonis-seumur-hidup?page=all dated 14 October 2020.

Detik.com. (2020) Eks Dirut Bank DKI Winny Erwindia Divonis 4 Tahun Penjara downloaded from https://news.detik.com/berita/d-2834887/eks-dirut-bankdki-winny-erwindia-divonis-4-tahun-penjara dated 14 October 2020.

Edj (2009). Dituduh Gunakan Harta Pailit Direksi TPI Dilaporkan Kurator downloaded from

https://money.kompas.com/read/2009/11/20/18394268/dituduh.gunakan.harta .pailit.direksi.tpi.dilaporkan.kurator dated 14 October 2020.

Hadyan, R. (2020) Survei ILO: Dua dari Tiga Perusahaan di Indonesia Berhenti Beroperasi downloaded from https://ekonomi.bisnis.com/read/20200518/12/1242174/survei-ilo-dua-daritiga-perusahaan-di-indonesia-berhenti-beroperasi date 23 April 2021.

Hasanah, S. (2019) Tanggung Jawab Direksi dan Komisaris Jika Perusahaan Pailit downloaded from https://www.hukumonline.com/klinik/detail/cl4898/tanggung-jawab-direksidan-dewan-komisaris-jika-perusahaan-pailit/ dated 18 October 2020. 
Hikam, H. A. A. (2019) Kronologi Kisruh Sushi Tei Vs Eks Dirut downloaded from https:/ finance.detik.com/berita-ekonomi-bisnis/d-4701012/kronologi-kisruhsushi-tei-vs-eks-dirut dated 18 October 2020.

Kencana, M. R. B, (2020). Chatib Basri: Akibat PSBB Perusahaan Menjadi Zombie Akibat Sulit Tutup Biaya Usaha downloaded from https:// www.liputan6.com/bisnis/read/4381091/chatib-basri-akibat-psbbperusahaan-jadi-zombie-akibat-sulit-tutup-biaya-usaha dated 14 October 2020.

Kusuma, H. (2020). Ramalan Terbaru IMF Ekoomi RI -1.5\% di 2020 downloaded from https:// finance.detik.com/berita-ekonomi-bisnis/d-5212852/ramalan-terbaruimf-ekonomi-ri-minus-15-di-2020 dated 14 October 2020

Liputan6.com (202) 40 Persen Swalayan di Indonesia Timur Tutup Imbas Pandemi Covid-19 downloaded from https://www.liputan6.com/bisnis/read/4402525/40persen-swalayan-di-indonesia-timur-tutup-imbas-pandemi-covid-19\# dated 23 April 2021.

Maulidya, I. (2020) 73 Perusahaan Lakukan PHK Hampir 15.000 Pekerja Jadi Pengangguran downloaded from https://economy.okezone.com/read/2020/07/10/320/2244240/73-perusahaanlakukan-phk-hampir-15-000-pekerja-jadi-pengangguran dated 14 October 2020

Parwito. (2020). Pailit Aset PT. Nyonya Meneer Harus Dilelang Untuk Lunasi Utang downloaded from https://www.merdeka.com/peristiwa/pailit-aset-ptnyonya-meneer-harus-dilelang-untuk-lunasi-utang.html dated 14 October 2020.

Septiadi, A. (2018). Tiga Direktur Ditahan Polisi, PKPU SNP Finance terhambat downloaded from https://nasional.kontan.co.id/news/tiga-direktur-ditahanpolisi-pkpu-snp-finance-terhambat dated 14 October 2020

Septiadi, A. (2020) Sengkarut BPKB Dalam Pailit Arjuna Finance downloaded from https://nasional.kontan.co.id/news/sengkarut-bpkb-dalam-pailit-arjuna-finance dated 14 October 2020.

Septiadi, A (2020). Pembelaan Manajemen Arjuna Finance Atas Kasus Utang Yang Membelitnya downloaded from https://nasional.kontan.co.id/news/pembelaan-manajemen-arjuna-finance-ataskasus-utang-yang-membelitnya dated 14 October 2020.

Sulaeman (2021) Menaker: 17,8 Persen Perusahaan PHK Karyawan Selama Pandemi Covid-19 downloaded from https://www.merdeka.com/uang/menaker-178perusahaan-phk-karyawan-selama-pandemi-covid-19.html\# dated 23 April 2021.

Susanto, V. Y. (2020) Tren Perkara PKPU Meningkat di Tengah Pandemi Covid-19 downloaded from https://nasional.kontan.co.id/news/tren-perkara-pkpumeningkat-di-tengah-pandemi-covid-19 dated 14 October 2020. 